\title{
Displaced Objects and Meanings. A Few Remarks on the Fang Mask, Masawa Canoes and Kachina Dolls
}

\begin{abstract}
Each of the artefacts mentioned in the title is an exemplification of products of the anthropological "Other”. Each of them comes from a distinct geographical region and represents an entirely different culture. However, all of them have been connected together in the Western culture realia as a result of a particular type of displacements. The first displacement involved their physical migration - first to European museums of natural history and ethnological museums. The next one resulted in their emergence on the market of exotic "oddities" whereas yet another displacement located them within the conceptual framework delimited by the artistic discourse. This last displacement shows that it is very difficult to understand or "translate" one culture into another because the conceptual framework of the "translator" is always determined by their own culture.
\end{abstract}

\section{Keywords:}

cultural anthropology, art history, anthropology of art

\section{INTRODUCTION}

The white mask of the Fang tribe inspired Picasso to paint a series of "African paintings”. Indian kachina dolls were collected by avant-garde artists - they used them as a source of creative inspiration. Trobriand masawa canoes were described by Bronisław Malinowski in his renown monograph: Argonauts of the Western Pacific, which has contributed to the transformation of cultural anthropology.

Inter-faculty Institute of Culture Studies and Art, University in Bialystok, Poland, E-MAIL: a.kisielewski@uwb.edu.pl. 
The above-mentioned artefacts may be treated as exemplifications of products of the anthropological "Other", which had never had anything in common with each other. They all came from distinct geographical regions and represented entirely different cultures. However, they were connected together in the Western culture as a result of a particular type of displacements. Thanks to the first one of them, which was a strictly physical migration of these objects to the Western world, they started to function as manifestations of cultures referred to as "aboriginal", “archaic”, "primitive”, "tribal” or "indigenous". These names - usually treated as synonyms - were a clear indication of the colonial attitude to non-European communities and a proof of the Western belief in the cultural "development" and "renaissance" character of colonization. The objects made by "primitive", nonEuropean communities were brought as exhibits to museums of natural history and ethnological museums. As a result of another displacement, a great number of such artefacts appeared in the early 20th century on flea markets and shops with "primitive" curiosities in big European cities, where they could be purchased, still for little money, by admirers of exotic otherness. At the same time, tribal artefacts were subjected to yet another displacement, which changed their status: they started to be associated with art thanks to being "discovered" by European artists. From that moment, they began to be treated as representations of "primitive" art.

The above-mentioned displacements were synonymous with tearing away the products of the 'Other' from their natural contexts created by the "aboriginal" reality with its constituent elements such as myths, religion, magic and ritual life. As a result, the displaced objects were deprived of their encoded primary sense because this sense has always reached only a limited circle of culture and art researchers. It may also be observed that the process of semantic shifts of meanings encoded in material artefacts produced by "primitive" communities is still in progress and its effects are difficult to predict.

\section{A FEW REMARKS ON THE FANG TRIBE MASK}

The Fang mask is considered to be the icon of modernist fascination with the form and a symbol of the sources of modernist art movements. As we know, the mask made a huge impression on Parisian artists. The first of them was Maurice de Vlaminck, the second - André Deraine and then Pablo Picasso, who under its influence "discovered" African art in Parisian Musée de Trocadéro, where, as he later reminisced, he supposedly understood its essence (Malraux, 1978, p. 13). He was mainly fascinated with its form. As a result of this fascination, he started to 
work on Les Demoiselles d'Avignon (Kisielewski, 2011, pp. 88-127). This renown painting by Picasso is considered to be a great breakthrough, especially from the point of view of American art history, because it opened the way to cubism, which is believed to be the dawn of modern art (Steinberg, 1972, pp. 22-29, 38-47).

However, the mask, which made such a big impression on Parisian artists, had never been an element of religious or magical rituals. According to William Rubin, an American art historian, it originates from the turn of the twentieth century and was a strictly commercial product, i.e. the Fang people used to make this kind of masks in order to sell it to tourists as souvenirs (Rubin, 1984, p. 13). It means that one of the most important impulses that triggered the development of modern art was an African souvenir made to be sold to European tourists. Today, the mask is kept at the Musée d'Art Moderne in Paris as a symbol of the birth of modern art.

The artists' interest in artefacts from Africa led to another displacement: as representations of l'art nègre they became the objects of admiration of European collectors. In 1920s, they were, in fact, an indispensable element of decoration of many Parisian artists' ateliers and then also of the studios of poets, writers, musicians and intellectuals, who were intrigued, most of all, by the visual form of these African artefacts - so different from the products of the European art. Their appearance in the spectrum of European art resulted also in some observations made by art critics and historians. An example of that are the texts by Guillaume Apollinaire and Negerplastik - the first critical review of African art in Europe by Carl Einstein, a German art historian and critic (Einstein, 1915). Einstein focused on a formal analysis of African masks and sculptures emphasizing their otherness when compared to the European sculpture. He also discussed the question of the relationship between African art and religion. That indicates the anthropological character of his observations and shows that he attempted to present the original meaning of tribal artefacts, which was quite exceptional at that time.

The displacement of African masks and sculptures into the Western world of art happened in the literal sense of the word, i.e. they entered that world also physically by being present in such institutions as art galleries or museums showing just art instead of "primitive" artefacts, as it was the case with ethnological museums. What is striking, though, is that African objects functioned as works of art mainly in the context of modern artworks, which means that the artistic "primitivism" from the Dark Continent was only supposed to legitimize the modern character of works made by Western artists. One might wonder, however, why would modern art need such legitimization. Such an attitude was indicated by numerous exhibitions. The first of them was the exhibition in Neue Galerie in Berlin in December 1913, where Picasso's Cubist drawings and paintings were presented together with 
African tribal sculpture, which was also shown the following year at Emil Richter's w Kunstsalon in Dresden. A similar exhibition was organized by a famous apologist of modern art - Alfred Stieglitz, a photographer, in his "291” gallery in New York in 1914. Although he presented there only traditional African sculpture, its placement in the context of Western modern art was clearly indicated by the very title of the exhibition: Statuary in Wood by African Savages: The Root of Modern Art (de Zayas, 1914). "Indigenous" art was hardly ever presented without a direct connection with modern art. One of such exceptional occasions was the art show entitled Premier expostion d'Art Nègre at d'Art Océanien, organized at Galerie Devambez in Paris in 1919 by a famous Parisian art dealer - Paul Guillaume.

The above-mentioned absorption of African objects by the Western institutionalized art world resulted in another displacement. It was a fashion for l'art nègre in Paris in the 1920s. Its meaningful representation could be the black African mask which Kiki de Montparnasse is holding at her face at the famous photograph by Man Ray, first published in the "Vogue" magazine in 1926. This famous fashion magazine was, first of all, the glorification of the visual. Fashion - as Jean Baudrillard observed many years later - is about creating enchanting images, whose role is not, however, to communicate any deeper sense (Baudrillard, 2005). The fashion for l'art nègre was also visible in the popularity of Josephine Baker's shows, jazz big bands composed of Black musicians or African patterns used in the mass production of textiles, furniture or small every day objects such as kitchen trays, tableware etc. The cause of popularity African motifs were not the meanings encoded in African masks or sculptures, which resulted from religiousness of their creators or their belief in the power of magic and emotions caused by the belief in the existence of mythical supernatural creatures. The public was attracted by the charm of exoticness and purely sensual pleasure derived from visual (or auditory in the case of jazz music) sensations. One of the examples of the fashion for l'art nègre was a big exposition organized in Paris in 1931, whose clearly colonial character was emphasized in its title: Exposition coloniale internationale.

In the second half of the 20th century, "primitive” objects were still displayed as art pieces side by side with Western art only in the context of the latter. It is illustrated, among others, by a great art exhibition presented on the occasion of 1972 Olympic Games in Munich, entitled: Weltkulturen und Moderne Kunst (Wichmann, 1972). The most famous example of this kind of presentation is a very well-known and highly criticized exhibition "Primitivism” in 20th Century Art, held at the prestigious Museum of Modern Art, New York, in 1984 (Rubin, 1984). Another equally famous and controversial exhibition was held in Paris in 1989, 
at Grande Halle de la Villette and Georges Pompidou Centre, under a poetic title: Magiciens de la Terre (Steeds, 2013). The criticism of the above-mentioned exhibitions, which could sometimes be very fierce and hostile, centred mainly on the fact that, in a truly Dadaistic way, they juxtaposed the works of art which had never had anything in common because they were the products of different cultures and manifestations of completely different ways of conceptualizing the reality (Foster, 1985, Danto, 1984, Clifford, 2000).

Another displacement exemplified by the Fang mask did not refer to the form but the meanings. It happened only in the second half of the 20th century. Thanks to this displacement, the West learned that the Fang tribe wore masks painted with white kaolin during rituals performed at meetings of secret societies, which only adult males could belong to. At the initiation ceremony for new members, they dressed in raffia costumes and put on masks very similar to the one held at the Parisian Musée d'Art Moderne. The ritual Fang masks were usually elongated or sometimes heart-shaped. They were covered in white kaolin with facial features outlined in black. White colour symbolized death, which is why the masks were treated as instruments to reconnect with the power of ancestors and the embodiment of the spirit of the dead. By putting on the mask, its wearer could embody the spirit of a dead ancestor and take over his power. The Africans believed that thanks to this a new member of the society became a living embodiment of a dead person.

The knowledge of meanings and their cultural contexts did not impact the Western culture as strongly as the fascination with the exotic form of "primitive" artefacts such as African masks or sculptures. Their aesthetics was an impulse which provoked very far-reaching changes in modern art and, in consequence, a transformation of the whole Western visual culture. The poetics of "primitive" rawness and simplicity - a perfect example of which could be the Fang mask - "matched" the later rawness and simplicity of modernist architecture and design, which became a constant element of everyday life environment of contemporary people. The sense of "primitive" sculptures and masks, determined by mythical thinking of their creators, was replaced in modern architecture and design by the myth of functionalism and economic efficiency.

Today, African masks and sculptures are sold on the Internet, shops with African art, professional art galleries as well as prestigious auctions held by great auction houses. L'art nègre can be bought at a little shop at the outskirts of Chinatown in Toronto. Or, we can get one at a website offering African masks, where we are reassured that they are original and come from a verified supplier in China. The art form the Dark Continent can also be very expensive. The highest price paid so far 
for an African work of art was EUR 5.9 million, which was obtained at an auction held at Drout hotel in Paris in 2006. The object of the auction was a 19th century Fang mask from Gabon (Nevadomsky, Půtová, Soukup, 2014, p. 85, notice 50)². This exorbitant price is a proof of another displacement of "tribal" objects - this time, in the hierarchy of values determined by the economy. Let us recall that in 1905 the Fang mask which is now displayed at the Parisian Musée d’Art Moderne was sold by Maurice de Vlaminck to André Deraine for 50 French francs, which was then a rough equivalent of a weekly wage earned by a house painter in Paris.

Finally, the last displacement should be mentioned. The aforementioned auction at Drouot hotel was held the day before the opening of Parisian Musée du Quai Branly, where a collection of "primitive" art is presented with an unprecedented support of digital technology. The descriptions of exhibits displayed at anthropological museums very rarely contain information about the meanings encoded therein. This Parisian museum is an exception in this respect. We have there flat screens mounted on the walls next to cabinets with African masks and sculptures, where visitors can watch films showing these objects in their natural context, e.g. during religious ceremonies or magical rituals with dance, music and signing. These digital displays include also the information about the senses encoded in particular artefacts. In this case, the representation of "primitive” (not only African) art, exemplified by the Fang mask, have been moved to digital space.

\section{A FEW REMARKS ON THE MASAWA CANOES}

Masawa canoes from the Trobriand Islands were big, heavy and cumbersome, which made their transportation expensive. For this simple reason, they appeared in ethnological museums (mainly Australian ones) quite late. However, they were never displayed in modern art museums nor were they traded or admired by collectors. Masawa canoes were brought to the Western world thanks to Bronisław Malinowski, who wrote about them in his popular monograph Argonauts of the Western Pacific, published in 1922. The ethnologist presented there in detail the process of boat construction locating it in the wider cultural context of the Trobriand Islands.

In Argonauts..., masawa canoes are presented as the most important manifestation of Trobriand creativity. These were large sea going boats, tailor-made for

See also: http://www.drouot.com/static/drouot_resultat_detail.html?idActu=6456 [access: 18.09 .2017$]$. 


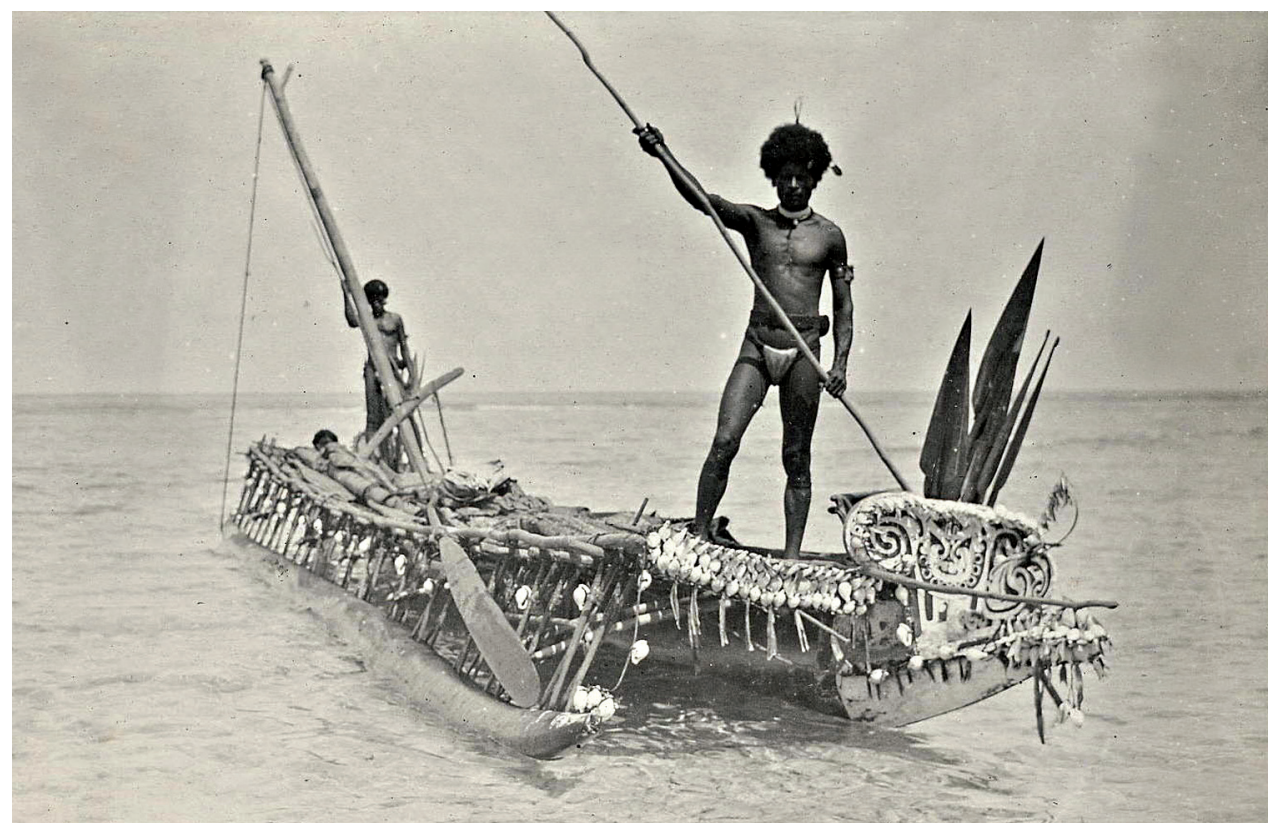

Photo 1. Canoes. Two men on canoe showing carved prow, C. 1915-1918. London School of Economics Library. Photo by Bronislaw Malinowski

Source: https://archives.Ise.ac.uk/Record.aspx?src=CalmView.Catalogctid=MALINOWSKI\%2f3\%2f4\% $2 f 8$

deep sea sailing connected with kula exchange. They were designed to carry heavy loads and take aboard even 20 sailors. The hull was made of a hollowed tree trunk with longitudinal planks, carved transversal prow boards and a stabilizing outrigger attached to the dugout. Between the hull and the outrigger, a wooden platform was placed and a mast with a triangular sail made of palm tree leaves was inserted. The paddles were leaf-shaped. The boats were decorated with, as Malinowski put it: "the most exquisite carvings", meticulously painted and ornamented, which made them powerful tools against nature and supernatural phenomena (Malinowski, 1987, p. 157). They were decorated with kauri shells, resonating in the wind and chiming melodies when the boat was rocking on the waves, as well pandanus streamers fluttering in the wind (Malinowski, 1987, p. 191).

Malinowski describes in detail the process of building a Trobriand canoe. He writes about magical rites performed at nearly each stage of its construction, which proves its ritual character. A special element of the canoe were its four prow boards, which were "beautifully carved and painted black, white and red" (Malinowski, 1987, p. 191). After they are inserted and the accompanying ritual is 


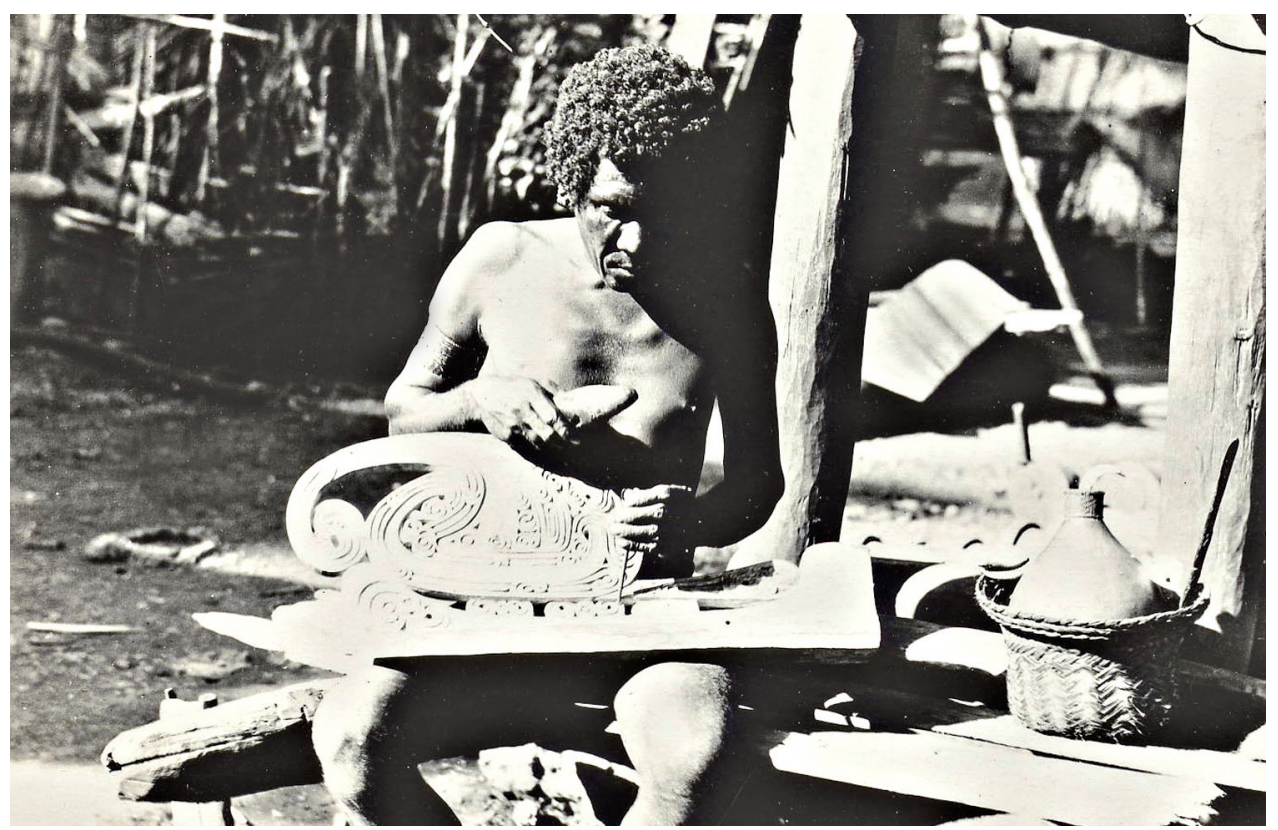

Photo 2. Tokabicam makes a canoe decorations, 1915-1918. London School of Economics Library

Source: https://archives.Ise.ac.uk/GetImage.ashx?db=Catalog\&type=defaultafname=Malinowski\%5c Malinowski_3_4_58.jpg

completed, another magical rite takes place, i.e. washing the boat in sea water in order to "remove the traces of any evil influence, which might still have remained" (Malinowski, 1987, p. 193). The magician performing this rite addressed the canoe as if it was a human being. Only when the canoe has been taken ashore and placed on wooden supports, the ornamented planks were attached. All elements of the boat were carefully matched and tied together, then the outrigger was inserted and the whole structure was caulked. The sail was made in one day. "The canoe is now ready for the sea, except for the painting, which is only for ornamentation" (Malinowski, 1987, p. 197). First, however, three more magical rites have to be performed in order to give the canoe appropriate speed.

Each masawa canoe was something special, it had a name and was treated as a living creature. Newly built canoes often took their names after their worn-out predecessors and were considered to be their reincarnations. They were stored in special warehouses, similar to residential houses but bigger.

Malinowski wrote: 
A new sailing craft is not only another utility created; it is more: it is a new entity sprung into being, something with which the future destinies of the sailors will be bound up, and on which they will depend (Malinowski, 1987, p.206).

The work on the canoe was a collective experience but its main constructor was usually just one person. It could be a highly qualified craftsman or carver called tokabitam, who also made carved prow boards and splashboards. He had a special status, which was emphasized by his special diet and customary compensation in the form of pigs, vegetables such as taro and yams or baskets full of bananas.

We believe that Bronisław Malinowski’s work may be treated as an anthropological ecphrasis about the art culture of Triobriand islanders. It lends itself very well to such a description. According to the ethnologist, the building of the canoe was a constant reproduction of archetypical visual forms as well as behaviour patterns and concepts and the task of the main builder of the canoe, tokabitam, was, in fact, to reproduce them carefully. Canoe building meant participating in a ritual and, at the same time, its restitution. It means that any innovation or "development" was out of the question. We may assume that the reproduction of archetypes, i.e. working on the canoe and the accompanying magical formulae and rituals, could have been taking place in an unchanged form for several thousand years. The builders had a great responsibility. Any transgression from the cultivation of archetypes could result in, for instance, making the canoe too slow or too cumbersome to manoeuvre, which could be very dangerous for sailing. Any departure from the fixed patterns or their careless reproduction could, in consequence, put sailors' lives in danger. In fact, we might say that the canoes were created by those archetypes because they determined the actions of Trobriand builders and their helpers.

Trobriand master craftsmen treated the canoes as if they were living creatures, actively participating in the social life of the community. Building and then sailing the canoe was equal to experiencing a special way of being, which consisted of going beyond common rationality and being aware of the existence of an ahistorical world in the sense defined by Mircea Eliade. It was connected with living in the world of nature and, at the same time, constantly entering the reality of the myth. It allowed for living on the border of the knowable and the unknowable, going beyond the strictly human world. Masawa canoes, which were very beautiful in Malinowski's opinion, thanks to his monograph, were displaced to the world of Western notions and concepts used in the discourse pertaining to cultural anthropology and - thanks to these remarks - also the anthropology of art. 
Compared to other representations of traditional African art, they were displaced to ethnological museums relatively late.

It should be remarked, however, that the Polish ethnologist did not classify Trobriand canoes as works of art. The first time the canoes were clearly located in the artistic discourse was in the work by an Australian ethnologist - Shirely Campbell, who analysed masawa canoes made on Vakuta island, where Malinowski spent only ten days in April 1818 (Malinowski, 2002, pp. 609-620). Campbell did her research in 1974. She spent eight months on the island and the effect of her stay there was a monograph entitled: The Art of Kula, which was not published until 2002 (Campbell, 2002). The researcher shows there that canoe ornamentation was a part of a larger visual system consisting of ornamentation in architecture, ornamentation of everyday objects and methods of body ornamentation. This system was closely related to the realm of myths, beliefs, superstitions, religious and magical rituals, i.e. the ways of conceptualizing reality. On the formal level, the visual system of islanders was derived in its entirety from the observation of nature.

The remarks on masawa canoes allow for making some constatations about modern art. Its point of reference is usually not nature but civilization, which, according to Martin Heidegger, cannot be referred to as culture but technical civilization. A modern artist very often treats his or her work as a tool used to comment on it or as a product of art. However, it is always the expression of the artist's private mythology.

\section{A FEW REMARKS ON KACHINA DOLLS}

Kachina dolls represent similar displacements as the Fang mask and the masawa canoe. In the Western world they appeared first as exhibits in ethnological museums. In 1894, they were for the first time the object of ethnographic research, which was dominated by the paradigm of "saving" or "collecting" and consisted mainly of stock taking and classification based on a formal analysis rather than uncovering the senses encoded therein (Fewkes, 1903, pp. 3-126). In the first half of the 20th century, the focus was still on analysing their stylistic layer and they were not connected with the whole Indian cultural system. In the late 19th century and early 20th century, the dolls started to function on the market - mainly thanks to Hopi Indians of Arizona and New Mexico, who started to organize ritual shows for white tourists and, at the same time, sold them their dolls (Phillips, Steiner, 1999). One of such tourists was an art historian - Aby Warburg, who in 1896 made 


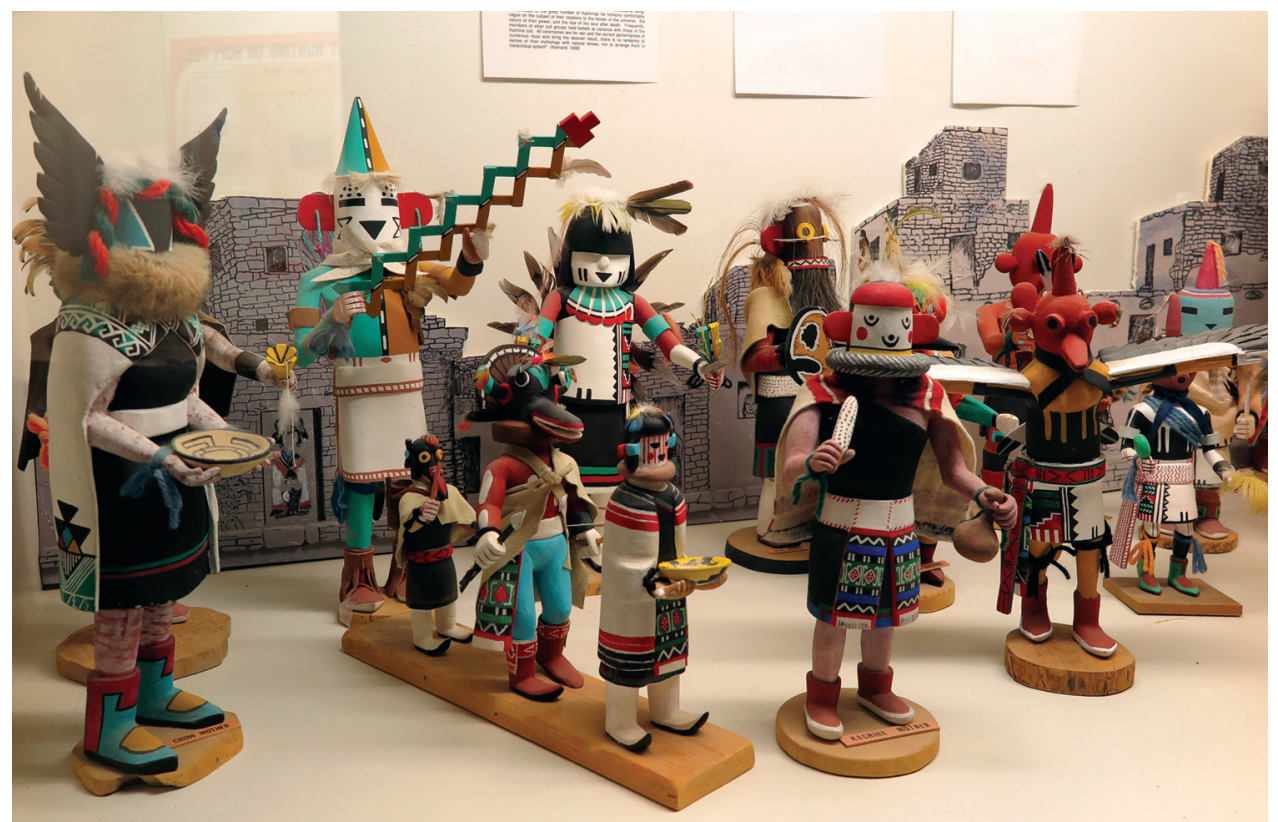

Photo 3. Kachina dolls. Museum Hopi Cultural Center, Arizona, USA

Source: photo by Andrzej Kisielewski

a legendary trip to Oraibi and Walpi in order to see Indian ritual dances, especially the famous snake dance (which he finally did not see for the lack of time) (Warburg, 2011, pp. 41-54). The trip, which Warburg's collaborator, an art historian, Fritz Saxle called “a journey to the archetypes” (Raulf, 2011, p. 69, notice 5), contributed to a significant displacement in the history of art. Under the influence of contacts with the "aboriginal" Indian culture, Warburg started to promote the history of image understood as the history of concept rather than works of art and their forms - against the formalist paradigm, which dominated the contemporary art history.

Hopi Indians usually made their kachina dolls from the roots of cotton trees. They also used authentic animal horns, fur, feathers, corn sprouts and wool. The dolls were characterized by very "modernist" poetics because they were determined by the language of geometry, whose components were straight lines, circles, squares and simple basic colours. However, they were in a certain way not obvious and full of secrets. A typical doll, perceived as an image or a surrogate of a human being, is a toy for girls, a marionette or a clothes dummy. Kachina dolls are not surrogates or images of people. Hence their otherness, which made quite 
an impression both on tourists visiting Hopi Indians in their country and artists in Europe. As mentioned before, in the 1920s, having a collection of "primitive" oddities in one's atelier or studio was fashionable, especially among Parisian artists, writers, poets and intellectuals. Kachina dolls were also considered to be oddities, just like African masks or sculptures from the Pacific Islands. One of such collectors was André Berton, who displayed his collection on the walls of his study in his Parisian studio at rue Fontaine. A collection of approximately two hundred dolls was owned by Max Ernst, who during his first trip in 1941 to the US State of Arizona bought them in a factory in Grand Canyon for the price of five-seven dollars each (Warlick, 2001, p. 204).

While the Fang mask is considered to be the source of modern art and the masawa canoe allowed for treating cultural anthropology as an ecphrasis about art, kachina dolls constantly intrigued numerous artists, stimulated their imagination and inspired their creativity. We can find many traces of such inspirations in the works by Ernst, Paul Klee and many more famous representatives of avantgarde. One of examples is the experiment of a renown avant-garde artist - Sophie Taeuber-Arp, who was interested in tribal cultures and, at one point, got inspired by Hopi dolls. She saw them at a famous Swiss psychoanalyst - Carl G. Jung and, under their influence, made two costumes based on the formal idiom of abstract Indian geometry - so close to modernist aesthetics. Inspired by the dolls, she also designed a number of modernist fabrics. Their colourful, geometric patterns were motivated by dolls' ornaments, which were very close to the aesthetics preferred by the artist, i.e. squares, rectangles, triangles and circles plus basic colours, which were considered to be the synonyms of modernism.

Only in the second half of the 20th century did ethnologists start to "discover" in kachina dolls the senses which had not been known before, the effect of which was a certain popularity of Hopi culture, manifested by numerous publications of books and albums. Their readers could learn that supernatural creatures - kachina lived first in the Underground, together with the Hopi. At one point, however, kachina decided to leave Indians but before they did, they taught them ritual dances and songs so that they could still contact the supernatural world (Waters, 1977, pp. 165-173). Kachina were considered to be the cosmic life energy which surrounds the Hopi in each sphere of their life and also after they die (Wright, 2008, pp. 111-121). The Hopi believed that after death each person becomes a kachina and comes back to his or her native land with life-giving rain. Kachina ceremonies reflect strictly the Hopi's traditional world view. Kachina beings played various roles in their world. First of all, they acted as spirits brining the rain and helping crops grow. Kachina functioned also as creatures disciplining tribesmen, both 
children and adults. As a result, both the former and the latter fulfilled their social functions better.

Kachina dolls were faithful reproductions of dancers, who, thanks to their costumes and masks worn during dances, impersonated kachina spirits, on whom the existence of Indians was always dependent. The dolls themselves were not perceived as sacred but kachina masks and dancers' costumes were treated as sacred and they were never reproduced or sold - this rule was observed by all Pueblo Indians, including the Hopi. Kachina dolls were given to girls and adult women, who put them on display in their homes. The dolls were not toys but children could play with them and often did. Their role was purely educational: they were supposed to make children familiar with kachina spirits. There were over three hundred of them and each one was pictured with a different mask and costume worn by a dancer. Warburg wrote about Hopi dances:

...masked dances are not child's play, but rather the primary pagan mode of answering the largest and the most pressing questions of the Why of things. In this way the Indian confronts the incomprehensibility of natural processes with his will of comprehension, transforming himself personally into a prime causal agent in the order of things. For the unexplained effect, he instinctively substitutes the cause in its most tangible and visible form. The masked dance is danced causality (Warburg, 2011, p. 52).

By transforming themselves into supernatural beings, dancers acted as mediators between people and the supernatural world. With their dances at the periodic festivals accompanying the annual harvest cycle, they tried to bring the rain. Indians inhabited the dry areas along the Rio Grande river, where they cultivated corn - the basis of their diet. Kachina dances were meant to ensure survival, which is why Indians had to dance very well. If one of them stumbled or fell down while dancing, it would not only be a sign of his immoderation but could nullify the whole ceremony and, consequently, bring drought and hanger due to the lack of crops (Waters, 1977, p. 167). One of the dances was the famous snake dance, which attracted a lot of tourists and which Aby Warburg wanted very much to see. During this ritual Indians impersonating kachina spirits dance with live venomous rattlesnakes in their mouths in order to beg their gods for the descent of rain. According to Indian beliefs, snakes were sent by gods and through this snake ritual the Hopi addressed to them their prayers for rain. Warburg watched the hemis kachina dance, i.e. the dance of germinating corn, and made a displacement, which was "re-discovered" and became meaningful only quite recently. He placed kachina dances not only in the context of the whole Hopi culture but also in the context of other cultures such as those of the ancient Greece, early Christianity 
or the Italian Renaissance. He discovered that in different cultures people have similar mechanisms of thinking and ways of using their imagination.

The commercial production of kachina dolls developed after World War II. First, however, numerous Indian artists made them for money. However, they also believed it to be an expression of their identity (Dunlop, 2004). Some of them started to sign their works, thanks to which kachina dolls stopped being anonymous works as it was the case in the past. Then, there appeared enterprises specializing in the commercial production of kachina dolls, which were sold to tourists in souvenir shops in Arizona and New Mexico and in museum shops. Porcelain kachina dolls started to be mass produced in Japan. Despite such a great popularity of kachina dolls, many kachina secrets have not been revealed yet and remain a well-protected mystery of the Hopi (Freedberg, 2011, p. 71).

\section{CONCLUSION}

The displacements referred to in the title may be a proof that in the Western civilization there is a demand for culture (if we agree to juxtapose culture and civilization) and, at the same time, authenticity. Modern civilization absorbs alien, non-European authentic artistic expressions and transforms them into something technical. An example of that is the absorption and transformation of exotic visual forms by modernist architecture and industrial design. What is problematic, however, is to get to the original sense contained in this initial, i.e. unprocessed form, which proves that it is very difficult and sometimes even impossible to understand or "translate" one culture into another because the conceptual framework of the translator is always determined by his/her own culture.

Such difficulties with translating of the intangible may be illustrated by these remarks on the three products of the anthropological "Other" listed in the title. Without having anything in common with each other - as it is underlined in the introduction - they "met” thanks to a certain kind of displacements into the industrialized Western world. One of such displacements situated them in the conceptual framework determined by the discourse of the anthropology of art and art history. A German art historian - Hans Belting had a clear opinion about them. He focused on the history of art, which, in his opinion "without hesitation declared everything as art so that they could claim its right to everything and by doing so, it levelled those differences, from which we could have obtained some knowledge about the topic of our concern” (Belting, 2010, p. 16). Based on Belting's opinion, we could assume that relativism is right and there is no reason why "primitive" artefacts 
should be classified as art. They would still be "primitive" artefacts. Relativism leads to a conclusion that objective truth does not exist, that our truth would be different from what is true for the members of the Fang tribe in Gabon, different for Malaysians from Trobriand Islands and different for the Hopi Indians. On the other hand, we may assume that art is an universal phenomenon although it may be expressed in very different ways. African masks and sculptures, masawa canoes and kachina dolls for many reasons differ clearly from European products of "the era of art", which, according to Belting, was born in Europe at the start of modernity and which is still doing quite well (Belting, 2010, p. 5). Nevertheless, we may assume that the objects named in the title represent the art culture of the societies still referred to as "aboriginal", "primitive" or "tribal”. It leads to a conclusion that they represent a "different" art - but still art, understood in a universal way, which, unfortunately, is an indication of the colonial character of both (in a sort of "by the way" manner) cultural anthropology, anthropology of art and art history.

Translated: Ewa Dobrogowska

\section{References}

Baudrillard, J. (2005). O uwodzeniu. Warszawa: Wydawnictwo Sic!.

Belting, H. (2010). Obraz i kult. Historia obrazu przed epokq sztuki. Gdańsk: Wydawnictwo słowo/obraz terytoria.

Campbell, S.F. (2002). The Art of Kula. Oxford-New York: Berg Publishers.

Clifford, J. (2000). Kłopoty z kulturq. Dwudziestowieczna etnografia, literatura i sztukq. Warszawa: Wydawnictwo KR.

Danto, A.C. (1984). Defective Affinities: “Primitivism” In 20th Century Art. The Nation, 239 (December 1), pp. 590-592.

Dunlop, S.B. (2004). Carving Self-Indentity. Hopi katsina Dolls as Contemporary Culture Expresion. Hamilton, Ontario, Canada: McMaster University, DOI: 11375/12977/1.

Einstein, C. (1915). Negerplastik. Leipzig: Verlag Der Wiessen Bücher.

Fewkes, J.W. (1903). Hopi Katcinas Drawn by Native Artist. In: Twenty-First Annual Report of The Bureau of American Ethnology to the Secretary of the Smithsonian Institution 1899-1900 by J.W. Powell (pp. 3-126). Washington: Government Printing Office.

Foster, H. (1985). The "Primitive” Unconscious of Modern Art, or White Skin Black Masks. October, 34 (Fall 1985), pp. 45-70.

Freedberg, D. (2011). Maska Warburga. Studium z zakresu idolatrii. Konteksty, 293-294 (2-3).

Kisielewski, A. (2011). Prymitywizm w sztuce awangardy pierwszej połowy XX wieku. Mitologie i obrazy pierwotności. Białystok: Wydawnictwo Uniwersytetu w Białymstoku.

Malinowski, B. (1987). Argonauci Zachodniego Pacyfiku. Warszawa: Państwowe Wydawnictwo Naukowe. 
Malinowski, B. (2002), Dziennik w ścisłym znaczeniu tego wyrazu. Kraków: Wydawnictwo Literackie.

Malraux, A. (1978). Głowa z obsydianu. Warszawa: Państwowy Instytut Wydawniczy.

Nevadomsky, J., Půtová, B., Soukup, V. (2014). Benin Art and Casting Technologies. West Bohemian Historical Review, 1 (vol. 4), p. 85, notice 50.

Phillips, R.B., Steiner, Ch.B. (Ed.) (1999). Unpacking Culture. Art and Commodity in Colonial and Postcolonial Worlds. Berkely: University of California Press.

Raulff, U. (2011). Siedem skór węża. Oraibi, Kreuzlingen i z powrotem: stacje na drodze ku światłu. Konteksty, 293-294 (2-3).

Rubin, W. (1984). Modernist Primitivism. An Introduction. In: W. Rubin (Ed.), "Primitivism” In 20th Century Art. Affinity of the Tribal and the Modern. New York: Museum of Modern Art.

Steinberg, L. (1972). The Philosophical Brothel. Art News, 5 (September 1972), pp. 22-29, 6 (October 1972), pp. 38-47.

Steeds, L. (Ed.) (2013). Making Art Global (2). 'Magiciens de la Terre’ 1989. London: Afterall Books.

Warburg, A. (2011). Obrazy z terytorium Indian Pueblo w Ameryce Północnej. Konteksty, 293-294 (2-3), pp. 41-54.

Warlick, M.E. (2001). Max Ernst and Alchemy. A Magician In Search of Myth. Austin: University of Texas Press.

Waters, F. (1977). Book of the Hopi. New York: Penugin Books.

Wichmann, S. (Ed.) (1972). Weltkulturen und Moderne Kunst. Die Begegung der europäische Kunst und Musik im 19. und 20. Jahrhundert mit Asien, Afrika, Oceanien, Afro- und IndoAmerika. München: Verlag Bruckmann.

Wright, B. (2008). Hopi Kachinas: A Life Force. In: E. Glenn, W.H. Rollings, J.R. Wunder, \& C.L. Martin (Eds.), Hopi Nations: Essays on Indigenous Art, Culture, History and Law, (pp. 111-121). Lincoln: University of Nebraska.

Zayas de, M. (1914). Statuary in Wood by African Savages: The Root of Modern Art. New York: Galery 291.

Zacharowska, M., Kamocki, J. (1984). Stefan Szolc-Rogoziński. Badania i kolekcja afrykańska z lat 1882 do 1890. Kraków: Muzeum Etnograficzne w Krakowie. 